\title{
Pengembangan LKPD inkuiri terbimbing untuk meningkatkan keterampilan berpikir kritis dan hasil belajar peserta didik
}

\author{
Muhammad Firdaus ${ }^{1}$ *, Insih Wilujeng ${ }^{2}$ \\ ${ }^{1}$ SMP Negeri 3 Awayan. Ajung, Tebing Tinggi, Balangan, Kalimantan Selatan, 71664, Indonesia \\ ${ }^{2}$ Program Studi Pendidikan IPA, Program Pascasarjana, Universitas Negeri Yogyakarta. \\ Jalan Colombo No. 1, Karangmalang, Yogyakarta, 55281, Indonesia. \\ * Corresponding Author. Email: muhammad.firdaus0110@gmail.com \\ Received: 30 September 2015; Revised: 12 February 2018; Accepted: 19 February 2018
}

\begin{abstract}
Abstrak
Penelitian ini bertujuan untuk: (1) mendeskripsikan karakteristik lembar kerja peserta didik (LKPD) inkuiri terbimbing; (2) mengetahui kriteria kelayakan LKPD inkuiri terbimbing; (3) mengetahui peningkatan keterampilan berpikir kritis dengan menggunakan LKPD yang dikembangkan, dan (4) mengetahui hasil belajar peserta didik dengan menggunakan LKPD yang dikembangkan. Penelitian ini menggunakan metode research and development (R\&D). Desain uji coba produk utama menggunakan LKPD inkuiri terbimbing pada kelas VIIA sebagai kelas eksperimen dan LKPD dari pendidik pada kelas VIIB sebagai kelas kontrol. Pengumpulan data menggunakan lembar observasi, angket, dan tes tertulis. Hasil penelitian ini berupa LKPD inkuiri terbimbing yang memiliki kategori sangat baik. Hasil pengembangan dan penelitian menunjukkan bahwa (1) karakteristik LKPD berbasis inkuiri terbimbing meliputi tahapan membuat prediksi, melakukan penyelidikan, mengumpulkan data, menginterpretasi data, dan mengembangkan kesimpulan; (2) kriteria kelayakan LKPD inkuiri terbimbing layak digunakan dalam pembelajaran IPA; (3) terjadi peningkatan keterampilan berpikir kritis peserta didik dengan total rerata gain score 0,43 ; dan (4) terjadi peningkatan hasil belajar peserta didik dengan total rerata gain score 0,34 .
\end{abstract}

Kata Kunci: LKPD inkuiri terbimbing, keterampilan berpikir kritis, hasil belajar

\section{Developing students worksheet on guided inquiry to improve critical thinking skills and learning outcomes of students}

\begin{abstract}
This study aims to: (1) explain the characteristics of student worksheet on guided inquiry; (2) determine the feasibility criteria of student worksheet developed; (3) determine the increase critical thinking skills using a student worksheet developed; and (4) determine learning outcomes of students using the student worksheet developed. This study was research and development $(R \& D)$ which adapted the model by Borg \& Gall. The design of the main field testing used a student worksheet on guided inquiry in class VIIA as an experimental class and student of class VIIB as the control class. The data were collected using observation sheets, questionnaires, and written tests. The results of this study is in the form of a student worksheet on guided inquiry whicht has very good category. Results of the development and research show that (1) the characteristics of student worksheet based on the guided inquiry covering the steps to make predictions, conduct experiments, collecting data, interpretation data, and develop conclusions; (2) The feasibility criteria of the student worksheet on guided inquiry deserves used in science teaching; (3) There is an increase in critical thinking skills of students with a total mean gain score of 0.43; and (4) There is an increase in learning outcomes of students with a total mean gain score of 0.34 .
\end{abstract}

Keywords: student worksheet on guided inquiry, critical thinking skills, learning outcomes

How to Cite: Firdaus, M., \& Wilujeng, I. (2018). Pengembangan LKPD inkuiri terbimbing untuk meningkatkan keterampilan berpikir kritis dan hasil belajar peserta didik. Jurnal Inovasi Pendidikan IPA, 4(1), 26-40. doi:http://dx.doi.org/10.21831/jipi.v4i1.5574

http://dx.doi.org/10.21831/jipi.v4i1.5574 


\section{PENDAHULUAN}

Ilmu Pengetahuan Alam (IPA) pada hakikatnya merupakan suatu kumpulan pengetahuan yang diperoleh melalui proses ilmiah dengan cara berpikir dan penyelidikan yang membentuk sikap ilmiah, dan berinteraksi dengan teknologi sehingga dapat diterapkan dalam kehidupan sehari-hari, baik di sekolah maupun di masyarakat (Buxton \& Provenzo, 2011, p. 6; Chiappetta \& Koballa, 2010, p. 105; Departemen Pendidikan Nasional, 2011, p. 4; Goldston \& Downey, 2013, p. 13; Pellegrino, Wilson, Koenig, \& Beatty, 2014, p. 40). Substansi mata pelajaran IPA pada kurikulum SMP adalah pembelajaran IPA secara terpadu. Keterpaduan Pembelajaran IPA yang dinyatakan dalam Depdiknas (2011, p.1) merupakan suatu pendekatan pembelajaran IPA yang memadukan berbagai bidang kajian IPA menjadi satu kesatuan bahasan. Dengan keterpaduan pembelajaran IPA tersebut, diharapkan peserta didik dapat menemukan sendiri berbagai konsep yang dipelajari secara menyeluruh (holistic) sehingga dapat memecahkan permasalahan dalam kehidupan sehari-hari. Pembelajaran terpadu tidak hanya memadukan bidang kajian IPA saja, tetapi juga memadukan keterampilan untuk memecahkan masalah.

Dengan menggunakan keterpaduan pembelajaran IPA diharapkan peserta didik dapat diarahkan pada pengalaman belajar untuk merancang dan membuat suatu karya melalui penerapan konsep IPA dan kompetensi bekerja ilmiah, serta dapat memotivasi dan memberikan kemudahan bagi peserta didik dalam melihat kegiatan dan ide berbeda yang terkait. Namun, ternyata hal ini tidak sesuai dengan kondisi di lapangan. Dari hasil observasi pendahuluan yang dilakukan di salah satu SMP, pembelajaran IPA yang ditemukan di lapangan masih terpisah dan tidak ada keterpaduan di dalamnya. Hal ini dikarenakan pelaksanaan pembelajaran IPA sebagian besar masih dilaksanakan secara terpisah yaitu masih sebagai bidang studi (Fisika, Kimia, dan Biologi), kurangnya pemahaman pendidik terhadap keterpaduan pembelajaran IPA dan belum banyak contoh perangkat keterpaduan pembelajaran IPA yang dapat diaplikasikan.

Salah satu kendala pendidik dalam menjabarkan perencanaan pembelajaran IPA secara terpadu adalah latar belakang pendidikan pendidik yang masih dalam satu disiplin ilmu, yaitu Biologi, Fisika, dan Kimia. Pendidik merasa kesulitan ketika harus menentukan tema yang sesuai dan mengkolaborasikan antara bidang kajian tersebut. Dampaknya, pelaksanaan pembelajaran IPA belum dapat dilaksanakan secara maksimal. Agar dapat melaksanakan proses pembelajaran yang efektif dan efisien maka perlu suatu keterpaduan pembelajaran IPA, salah satunya menggunakan pendekatan tematik sebagai pendekatan dalam pembelajaran IPA.

Menurut Trianto (2010, p. 41) model keterpaduan webbed merupakan model pembelajaran terpadu menggunakan pendekatan tematik sebagai penggabung bahan dan kegiatan pembelajaran. Pendekatan ini diawali dengan menentukan tema dan subtema dengan memperhatikan keterkaitannya dengan mata pelajaran yang terkait. Tema dapat mengikat kegiatan pembelajaran, baik dalam mata pelajaran tertentu maupun antar mata pelajaran.

Model keterpaduan pembelajaran tidak hanya model webbed, (Fogarty, 2009, p. xv) menyebutkan bahwa ada sepuluh jenis model keterpaduan pembelajaran dalam kurikulum. Jenis model tersebut adalah fragmented (terpotong), connected (terhubung), nested (tersarang), sequenced (terurut), shared (terbagi), webbed (terjaring), threaded (tertali), integrated (terpadu), immersed (terbenam), dan networked (jaringan). Pada pembelajaran terpadu model webbed, sedapat mungkin tema yang diambil merupakan fenomena atau fakta yang terjadi dalam kehidupan sehari-hari dan dekat dengan lingkungan peserta didik.

Berdasarkan permendikbud nomor 61 tahun 2014 tentang KTSP pada pendidikan dasar dan menengah, masing-masing daerah memerlukan pendidikan yang sesuai dengan karakteristik daerah dan pengalaman hidup sehari-hari (Peraturan Menteri Pendidikan dan Kebudayaan Republik Indonesia, 2014, p. 3). Tema pembelajaran IPA yang digunakan sebagai penggabung pembelajaran adalah tema Gunung Meletus. Pemilihan tema ini didasarkan pada kondisi alam di SMP Negeri 2 Cangkringan Kabupaten Sleman, Yogyakarta yang mempunyai gunung berapi aktif, yaitu gunung Merapi. Tema yang dipilih berdasarkan fenomena atau hal-hal yang terjadi dalam kehidupan sehari-hari dan dekat dengan lingkungan peserta didik. Di samping itu, gunung Merapi yang aktif dapat meletus kapan saja, sehingga pengetahuan tentang hal yang terkait peristiwa gunung meletus perlu diketahui oleh peserta didik dan masyarakat. 
Penelitian Zulaiha, Liliawati, \& Ramalis (2014, pp. 22-27) menyebutkan bahwa pembelajaran terpadu tema Gunung Meletus menggunakan model keterpaduan webbed dapat meningkatkan hasil belajar siswa (knowledge domain, process of science domain, dan creativity domain). Hal ini disebutkan karena ketertarikan peserta didik terhadap pembelajaran menggunakan tema Gunung Meletus dan pentingnya pembelajaran tersebut bagi kehidupan mereka, sehingga ada motivasi yang besar untuk mengikuti pembelajaran dengan serius.

Peristiwa gunung meletus merupakan salah satu peristiwa atau kejadian di alam yang mana perlu dipelajari oleh peserta didik dalam pembelajaran IPA. Hal-hal yang dapat dipelajari dan diajarkan kepada peserta didik antara lain arus konveksi, proses meletus gunung berapi, dampaknya bagi makhluk hidup dan lingkungan, serta mitigasi bencana. Pembelajaran IPA dengan tema ini merupakan pembelajaran yang menekankan pada pemberian pengalaman belajar secara langsung melalui pendekatan inkuiri terbimbing yang diharapkan dapat menumbuhkan kemampuan berpikir, bekerja, dan bersikap ilmiah serta mengkomunikasikannya sebagai aspek penting kecakapan hidup. Kementerian Pendidikan dan Kebudayaan (2014) menyebutkan bahwa proses pembelajaran IPA yang dilaksanakan secara inkuiri ilmiah melalui keterampilan proses dapat menumbuhkan kemampuan berpikir, bekerja, dan bersikap ilmiah serta dapat mengkomunikasikannya sebagai aspek kecakapan hidup.

Inkuiri terbimbing menawarkan suatu penyelidikan yang terintegrasi, direncanakan, dan dibimbing oleh pendidik untuk membantu peserta didik mendapatkan dan mengembangkan pemahaman yang lebih baik mengenai konsep pengetahuan dan keterampilan yang diperlukan untuk dapat digunakan di kehidupan sehari-hari (Kuhlthau, Maniotes, \& Caspari, 2007, p. 1). Implikasi penting untuk mengajar dan belajar mengenai IPA melalui penyelidikan adalah dengan menyoroti aspek kognitif dan prosedural untuk mempersiapkan penyelidikan. Pendidik perlu mempersiapkan dua jenis pengetahuan peserta didik sebelum melakukan percobaan. Pertama, pengetahuan deklaratif (kognitif) yang mengacu pada konsep IPA untuk melakukan penyelidikan. Kedua, pengetahuan prosedural yang mengacu pada keterampilan dan proses penyelidikan ilmiah (Poon, Lee, Tan, \& Lim, 2012, pp. 303-327).
Pembelajaran IPA juga harus memfasilitasi peserta didik untuk berpikir dan berbicara melalui minds-on dan beraktivitas (proses ilmiah) melalui hands-on (Chiappetta \& Koballa, 2010, p. 105; Prasetyo, 2013, p. 2). Pembelajaran IPA melalui hands-on dapat memberikan peserta didik kesempatan untuk terlibat dalam eksplorasi dengan konten IPA, tidak hanya memberikan pengalaman belajar tentang konten IPA tetapi juga kemampuan penalaran dan penyelidikan (Foley, Mcphee, \& Consulting, 2008, p. 2). Di samping itu, pembelajaran IPA menggunakan kegiatan proses penyelidikan melalui hands-on dan minds-on dapat melibatkan peserta didik untuk mengembangkan keterampilan proses seperti menanya, mengamati, menghipotesis, memprediksi dan mengumpulkan data, merekam atau mencatat, menganalisis dan menginterpretasi data (Stoffels, 2005, p. 148).

Aktivitas hands-on dapat menggunakan metode laboratorium atau eksperimen yang menyediakan beberapa alat dan bahan yang dapat membantu peserta didik dalam mempelajari gejala dan kejadian alam seperti keadaan sebenarnya (Prasetyo, 2013, p. 2). Salah satu alat atau media untuk membantu peserta didik dalam mempelajari gunung meletus adalah melalui LKPD. LKPD merupakan lembar kegiatan proses pembelajaran untuk menemukan konsep IPA baik itu melalui teori, demonstrasi, maupun penyelidikan yang disertai dengan petunjuk dan prosedur kerja yang jelas untuk melatih keterampilan berpikir dan keterampilan proses IPA dalam menyelesaikan tugas sesuai dengan indikator pembelajaran yang ingin dicapai. LKPD dapat memudahkan guru untuk mengarahkan peserta didik untuk menemukan konsep IPA melalui percobaan atau penyelidikan baik itu secara sendiri ataupun berkelompok (Erminingsih, Sudarisman, \& Suparmi, 2012, pp. 203-210; Foley et al., 2008, p. 2; Hermanto, Prastiwi, \& Rosdiana, 2014, pp. 369-377; Sanni \& Lestari, 2011, pp. 902-903; Trianto, 2010a, p. 222). LKPD yang dimaksud dalam penelitian ini merupakan kumpulan lembaran kertas berukuran B5 $(25,7 \mathrm{~cm} \times 18,2 \mathrm{~cm})$ yang dijilid rapi dengan dilengkapi cover; berisi halaman judul, kata pengantar, petunjuk pembelajaran, daftar isi, pendahuluan, isi, penutup, daftar pustaka atau bibliografi, dan lampiran; mempunyai kegiatan atau aktivitas yang harus dikerjakan peserta didik; serta digunakan pendidik sebagai media dalam proses pembelajaran. 
LKPD merupakan salah satu instrumen perangkat pembelajaran yang sering digunakan dalam proses pembelajaran di kelas oleh guru. Menurut Yuniasih (2011, p. ii), pembelajaran IPA dengan menggunakan LKPD be a scieantist pada peserta didik kelas VII SMP dapat meningkatkan keterampilan proses IPA peserta didik. Untuk mewujudkan pembelajaran IPA yang sesuai dengan hakikatnya perlu dikembangkan suatu perangkat pembelajaran IPA, salah satunya diwujudkan melalui sebuah LKPD berbasis inkuiri terbimbing.

LKPD berbasis inkuiri terbimbing adalah media pembelajaran berupa kumpulan lembaran kertas berukuran B5 yang dijilid rapi menggunakan kawat spiral; dilengkapi cover; berisi halaman judul, kata pengantar, petunjuk pembelajaran, daftar isi, pendahuluan, kegiatan inkuiri terbimbing, penutup, bibliografi, dan lampiran; kegiatan inkuiri terbimbing memiliki tahapan membuat prediksi, melakukan penyelidikan, mengumpulkan data, menginterpretasi data, dan mengembangkan kesimpulan. Melalui LKPD ini diharapkan pengetahuan dan keterampilan yang diperoleh peserta didik tidak hanya hasil dari mengingat fakta dan kejadian tetapi juga hasil dari menemukan sendiri sebuah konsep IPA sehingga kemampuan berpikir kritis dan hasil belajarnya meningkat.

Keterampilan berpikir kritis yang dimaksud dalam penelitian ini adalah kemampuan analitis dan evaluatif peserta didik untuk mengolah informasi dan pengalaman yang diperoleh dalam proses pembelajaran, dengan indikator keterampilan menginterpretasi, menganalisis, mengevaluasi, menjelaskan, dan membuat kesimpulan. Keterampilan berpikir kritis akan membuat peserta didik mampu membuat keputusan atau tindakan terhadap permasalahan yang dihadapi. Keterampilan berpikir kritis ini akan membekali peserta didik dalam menghadapi setiap permasalahan yang dijumpainya dalam kehidupan sehari-hari (Facione, 2013, pp. 1-28; Ministry of Education Malaysia, 2002, pp. 4-5). Chase, Pakhira, \& Stains (2013, p. 410) menyebutkan bahwa peserta didik yang mengeksplorasi percobaan melalui serangkaian pertanyaan dapat membantu peserta didik mengembangkan pemahaman tentang konsep dengan mendorong mereka untuk berpikir kritis.

Hasil belajar yang dimaksud dalam penelitian ini adalah kemampuan domain kognitif yang diperoleh peserta didik pada saat dan setelah proses pembelajaran. Domain kognitif hasil belajar yang diperoleh peserta didik meliputi kemampuan mengingat $\left(\mathrm{C}_{1}\right)$, memahami $\left(\mathrm{C}_{2}\right)$, menerapkan $\left(\mathrm{C}_{3}\right)$, dan menganalisis $\left(\mathrm{C}_{4}\right)$. Kemampuan mengingat adalah kemampuan peserta didik untuk memanggil kembali pengetahuan dari pelajaran sebelumnya. Kemampuan memahami adalah kemampuan peserta didik untuk membangun pengertian dan penjelasan pada saat dan setelah proses pembelajaran. Kemampuan menerapkan adalah kemampuan peserta didik untuk melakukan prosedur percobaan yang sesuai dengan apa yang terjadi maupun pada situasi dan tugas yang baru. Kemampuan menganalisis merupakan kemampuan peserta didik untuk menguraikan, menghubungkan, dan menjelaskan suatu materi atau data pada saat dan setelah pembelajaran (Anderson \& Krathwohl, 2010, pp. 99-133).

Peserta didik belajar dan memperoleh pengetahuan serta membangun konsep mereka sendiri melalui pembelajaran inkuiri terbimbing. Melalui pembelajaran menggunakan pendekatan inkuiri terbimbing, secara perlahan peserta didik dapat belajar cara mengorganisasikan dan mengadakan penelitian agar konsep yang didapatkan mudah diingat oleh peserta didik. Peserta didik belajar membuat prediksi, melalui pengamatan percobaan peserta didik mengumpulkan data, menganalisis dan menginterpretasi data, serta mengembangkan kesimpulan. Oleh karena itu perlu untuk membelajarkan IPA menggunakan pendekatan inkuiri terbimbing.

Hasil penelitian Blanchard et al. (2010, pp. 577-616) menemukan bahwa peserta didik yang menerima pembelajaran melalui percobaan laboratorium berbasis inkuiri terbimbing cenderung memiliki skor nilai yang lebih besar di berbagai jenis pengetahuan (nilai tes konseptual, prosedural, dan pertanyaan mengenai IPA) dan retensi umum jangka panjang yang lebih baik daripada peserta didik dalam pembelajaran melalui laboratorium secara tradisional. Pembelajaran dengan penyelidikan dapat menghasilkan pembelajaran yang lebih bagi peserta didik, hal ini terbukti dari nilai tes standar yang memiliki rerata lebih tinggi apabila dibandingkan dengan pembelajaran tradisonal.

Berdasarkan hasil observasi pendahuluan dengan guru di SMP, LKPD yang digunakan masih berupa LKPD biasa yang banyak dijual di pasaran, dan LKPD tersebut juga tidak memiliki materi berkenaan dengan gunung berapi. Selain itu juga LKPD tersebut belum memunculkan keaktifan peserta didik, tidak pada keterampilan proses dan berpikir kritis. Sehingga pembelajaran IPA belum sepenuhnya menggunakan 
pendekatan scientific, seperti halnya pendekatan inkuiri terbimbing. Oleh karena itu diperlukan suatu LKPD berbasis inkuiri terbimbing dengan tema Gunung Meletus untuk peserta didik di SMP Negeri 2 Cangringan.

Tujuan pengembangan produk LKPD tema Gunung Meletus menggunakan pendekatan inkuiri terbimbing dimaksudkan untuk meningkatkan keterampilan berpikir kritis dan hasil belajar peserta didik, yang mana juga nantinya diharapkan diikuti dengan meningkatnya keterampilan proses peserta didik. Di samping itu produk LKPD tema Gunung Meletus berbasis inkuiri terbimbing belum pernah dikembangkan dan dibelajarkan di sekolah tersebut, sehingga peneliti berkeinginan untuk mengenalkan produk LKPD tema Gunung Meletus berbasis inkuiri terbimbing. LKPD tema Gunung Meletus berbasis inkuiri terbimbing menyajikan percobaan arus konveksi, erupsi gunung berapi, aliran lava, kekentalan magma, dan bahaya letusan gunung berapi dengan tahapan membuat prediksi, melakukan penyelidikan, mengumpulkan data, menginterpretasi data, dan mengembangkan kesimpulan. Sehubungan dengan itu, perlu untuk melakukan penelitian mengenai pengembangan LKPD tema Gunung Meletus berbasis inkuiri terbimbing untuk meningkatkan keterampilan berpikir kritis dan hasil belajar peserta didik di SMP Negeri 2 Cangkringan.

\section{METODE}

Metode penelitian yang digunakan adalah penelitian dan pengembangan (Research and Development) dengan mengadaptasi dari model pengembangan Borg \& Gall. Tahapan penelitian yang dilakukan mengambil tahapan kesatu sampai ketujuh dari 10 tahapan yang dirancang Borg \& Gall (Borg \& Gall, 1983, pp. 775-776). Tujuan dari penelitian dan pengembangan pada penelitian ini hanya sampai pada menghasilkan produk, tidak sampai pada tahapan diseminasi dan implementasi.

Penelitian ini dilakukan mulai bulan Januari 2015 sampai dengan bulan April 2015 pada semester II Tahun Ajaran 2014/2015 di SMP Negeri 2 Cangkringan Kabupaten Sleman, Yogyakarta.

Subjek penelitian untuk uji coba produk yang dikembangkan dalam penelitian ini adalah peserta didik kelas VIIA. Subjek uji coba terbatas (produk awal) adalah 10 peserta didik dari kelas VIII (yang telah mendapatkan materi gunung berapi) yang dipilih secara acak. Subjek uji coba lapangan (produk utama) adalah peserta didik kelas VIIA dengan jumlah 32 peserta didik, ditetapkan sebagai kelas eksperimen. Kelas kontrol adalah kelas VIIB dengan jumlah 32 peserta didik.

Prosedur pengembangan LKPD tema Gunung Meletus berbasis inkuiri terbimbing meliputi 7 tahap, yaitu (1) penelitian pendahuluan; (2) perencanaan; (3) pengembangan produk awal; (4) uji coba produk awal; (5) revisi produk awal; (6) uji coba produk utama; dan (7) revisi produk utama.

Penelitian pendahuluan dilakukan dengan cara: (1) studi pustaka dan (2) survei lapangan. Studi pustaka dilakukan pada standar kompetensi (SK) dan kompetensi dasar (KD) kurikulum 2006 mata pelajaran IPA SMP sebagai dasar untuk pemetaan keterpaduan materi. Survei lapangan dilakukan dengan teknik wawancara. Wawancara dilakukan terhadap kepala sekolah, guru IPA, dan peserta didik dengan mengajukan beberapa pertanyaan terkait pelaksanaan pembelajaran IPA. Berdiskusi dengan pendidik IPA di SMPN 2 Cangkringan mengenai RPP dan LKPD yang berkaitan dengan materi gunung api saat tahun pelajaran 2013/2014.

Perencanaan pengembangan produk awal LKPD tema Gunung Meletus berbasis inkuiri terbimbing meliputi 2 tahap, yaitu (1) pembuatan spesifikasi produk awal, LKPD yang dikembangkan menggunakan langkah kegiatan proses IPA dengan berpedoman pada sintak pembelajaran inkuiri terbimbing. Tahapan inkuiri terbimbing yang terdapat dalam LKPD meliputi membuat prediksi, melakukan penyelidikan, mengumpulkan data, menginterpretasi data, dan mengembangkan kesimpulan; dan (2) pembuatan analisis pemetaan keterpaduan $\mathrm{KD}, \mathrm{KD}$ yang digunakan dalam analisis keterpaduan hanya terbatas pada KD IPA SMP yang berkaitan dengan materi gunung api. Pemilihan cakupan KD hanya pada SMP bertujuan agar produk yang dihasilkan dapat digunakan untuk mengukur keterampilan berpikir kritis dan hasil belajar kognitif peserta didik SMP di akhir materi.

Tahap pengembangan produk awal bertujuan untuk mengembangkan produk LKPD tema Gunung Meletus berbasis inkuiri terbimbing yang mempunyai karakteristik indikator keterampilan berpikir kritis. Hasil pengembangan produk awal yang diarahkan oleh dosen pembimbing nantinya akan divalidasi oleh validator ahli, guru IPA, dan teman sejawat. Hasil validasi digunakan sebagai dasar untuk 
merevisi produk awal LKPD tema Gunung Meletus berbasis inkuiri terbimbing.

Setelah dinyatakan layak untuk diujicobakan maka LKPD ini nantinya akan diujikan kepada 10 peserta didik dalam uji coba produk awal. Peserta didik diminta untuk memberikan feedback terhadap LKPD yang dikembangkan berupa respon peserta didik pada angket yang telah diberikan. Berdasarkan hasil uji coba yang dilakukan dan tanggapan yang diberikan peserta didik, LKPD kemudian direvisi. Setelah mengumpulkan semua informasi data pendukung dalam uji coba produk awal, maka langkah selanjutnya melakukan revisi terhadap produk awal. Revisi produk awal bertujuan untuk melakukan perbaikan dan penyempurnaan terhadap produk utama berdasarkan hasil uji coba produk awal dan angket respon peserta didik. Semua informasi dan tanggapan atas perbaikan produk awal dilakukan untuk menghasilkan produk utama.

Tahap selanjutnya adalah uji coba produk utama. Tahapan ini sama dengan uji coba produk awal, hanya jumlah peserta didik lebih banyak, yaitu 32 peserta didik. Penentuan kelas yang diberikan perlakuan dengan menggunakan LKPD tema Gunung Meletus berbasis inkuiri terbimbing dilakukan secara acak. Hasil dari uji coba produk utama akan dianalisis berdasarkan hasil observasi, tanggapan, dan saran. Uji coba produk utama juga bertujuan untuk mengetahui hasil penerapan LKPD tema Gunung Meletus berbasis inkuiri terbimbing terhadap keterampilan berpikir kritis dan hasil belajar kognitif peserta didik. Untuk mengetahui peningkatan keterampilan berpikir kritis dan hasil belajar kognitif peserta didik dilakukan dengan uji awal dan uji akhir (pretest dan posttest).

Berdasarkan hasil uji coba produk utama, produk utama direvisi berdasarkan hasil analisis dari data informasi observasi, tanggapan, dan saran. Hasil revisi produk utama akan menghasilkan produk akhir LKPD tema Gunung Meletus berbasis inkuiri terbimbing yang telah diketahui kelayakannya.

\section{Teknik dan Instrumen Pengumpulan Data}

Teknik Pengumpulan Data

Teknik pengumpulan data pada penelitian ini meliputi: (1) penilaian kelayakan LKPD yang dikembangkan; (2) observasi keterlaksanaan rencana pelaksanaan pembelajaran (RPP); (3) tes tertulis; dan (4) angket.
Penilaian kelayakan LKPD tema Gunung Meletus berbasis inkuiri terbimbing dilakukan oleh 2 orang validator ahli (ahli materi dan media), 2 orang Guru IPA, dan 2 orang teman sejawat. Aspek penilaian LKPD yang dikembangkan meliputi kelengkapan komponen LKPD, kesesuaian isi dan materi, kesesuaian syarat inkuiri terbimbing, kesesuaian syarat konstruksi, dan kesesuaian syarat teknis. Skor penilaian terdiri atas 4 kategori skala penilaian, yaitu sangat kurang (skor 1), kurang (skor 2), baik (skor 3), dan sangat baik (skor 4).

Observasi keterlaksanaan RPP dilakukan untuk mengukur keterlaksanaan pembelajaran menggunakan LKPD berbasis inkuiri terbimbing yang dilakukan oleh dua orang observer. Aspek yang diobservasi meliputi kegiatan awal, inti, dan akhir berdasarkan langkah-langkah yang terdapat di RPP dan telah sesuai dengan sintak pembelajaran berbasis inkuiri terbimbing. Observer mencatat hasil pengamatan pada kategori yang muncul dengan cara memberi tanda centak $(\sqrt{ })$ pada kolum yang sesuai (kolum "ya" atau "tidak"). Skor penilaian yang diberikan terhadap masing-masing aspek yaitu skor 1 apabila memberi tanda pada kolum "ya" dan skor 0 apabila memberi tanda pada kolum "tidak".

Tes tertulis digunakan untuk mengukur keterampilan berpikir kritis dan hasil belajar peserta didik. Tes tertulis yang dilakukan terdiri dari 2 bentuk soal, yaitu soal uraian dan pilihan ganda. Soal bentuk uraian digunakan untuk mengukur keterampilan berpikir kritis peserta didik dan soal bentuk pilihan ganda untuk mengukur hasil belajar peserta didik. Soal bentuk pilihan ganda terdiri atas 16 soal dengan skor penilaian masing-masing soal adalah 0 dan 1. Soal bentuk uraian terdiri atas 6 soal dengan masing-masing soal memiliki skor 1 sampai dengan 4. Tes tertulis ini diberikan dua kali yaitu sebelum menggunakan produk pengembangan (pretest) dan setelah menggunakan produk pengembangan (posttest).

Angket digunakan untuk mengetahui respon peserta didik tentang kelayakan produk awal LKPD yang dikembangkan ditinjau dari syarat didaktik, syarat konstruksi, dan syarat teknis. Skala penilaian yang digunakan adalah skala 5 (lima) dengan pilihan sangat setuju (skor 5), setuju (skor 4), kurang setuju (skor 3), tidak setuju (skor 2), dan sangat tidak setuju (skor 1). 


\section{Instrumen Pengumpulan Data}

Instrumen yang digunakan untuk mengumpulkan data meliputi: (1) lembar validasi LKPD; (2) lembar observasi keterlaksanaan RPP; (3) lembar pretest dan posttest; dan (4) lembar angket.

Instrumen lembar validasi LKPD digunakan untuk memperoleh data tentang penilaian, komentar, dan saran dari validator ahli, guru IPA, dan teman sejawat. Lembar observasi keterlaksanaan RPP untuk mengukur keterlaksanaan pembelajaran menggunakan LKPD berbasis inkuiri terbimbing yang dilakukan oleh dua orang observer. Sebelum lembar observasi digunakan, instrumen ini terlebih dahulu divalidasi oleh ahli pembelajaran.

Instrumen tes tertulis berupa soal pilihan ganda dan uraian. Soal pilihan ganda ini digunakan untuk mengukur hasil belajar kognitif peserta didik. Soal pilihan ganda terdiri atas 16 soal. Instrumen soal berupa uraian berisi pertanyaan mengenai materi tema Gunung Meletus yang digunakan untuk mengukur keterampilan berpikir kritis peserta didik. Soal uraian terdiri atas 6 soal. Lembar angket digunakan untuk mengetahui respon peserta didik tentang kelayakan produk awal LKPD yang dikembangkan ditinjau dari syarat didaktik, syarat konstruksi, dan syarat teknis.

\section{Teknik Analisis Data}

Teknik analisis data untuk kelayakan LKPD dilakukan dengan langkah sebagai berikut (1) tabulasi semua data yang diperoleh dari validator ahli (materi dan media), guru IPA, dan teman sejawat untuk setiap aspek dari butir penilaian yang tersedia dalam instrumen penilaian; (2) tabulasi semua data yang diperoleh dari angket respon peserta didik; (3) skor rerata dihitung dari setiap aspek penilaian dengan menggunakan rumus: $\bar{X}=\sum x / n$, di mana $\overline{\mathrm{X}}$ adalah nilai rerata skor, $\sum x$ adalah jumlah skor yang diperoleh seluruhnya, dan $n$ adalah jumlah penilai; dan (4) rerata skor diubah menjadi nilai dengan kategori.

Untuk mengetahui kelayakan LKPD tema Gunung Meletus berbasis inkuiri terbimbing yang dikembangkan, data yang mula-mula berupa skor diubah menjadi data kualitatif (data interval) dengan skala lima. Konversi skor menjadi nilai menggunakan dasar kurva normal. Hal ini bertujuan agar rentang skala nilai memiliki jarak yang sama. Untuk mengkonversi skor menjadi skala 5, perlu diketahui skor tertinggi dan terendah ideal, rerata skor ideal, dan simpangan baku skor ideal. Adapun acuan pengkonversian skor menjadi skala lima tersebut seperti yang disajikan pada Tabel 1 (Sukardjo, 2013, p. 96).

Tabel 1. Konversi Skor Aktual Menjadi Skala 5

\begin{tabular}{cccc}
\hline No & Rentang skor & Nilai & Kategori \\
\hline 1. & $\mathrm{X}>\bar{x}+1,80 \mathrm{Sb} i$ & $\mathrm{~A}$ & Sangat Baik \\
2. & $\bar{x}+0,60 \mathrm{SB} i<\mathrm{X} \leq \bar{x}+1,80$ & $\mathrm{~B}$ & Baik \\
& $\mathrm{Sb} i$ & & \\
3. & $\bar{x}-0,60 \mathrm{SB} i<\mathrm{X} \leq \bar{x}+0,60$ & $\mathrm{C}$ & Cukup Baik \\
& $\mathrm{Sb} i$ & & \\
4. & $\bar{x}-1,80 \mathrm{SB} i<\mathrm{X} \leq \bar{x}-0,60$ & $\mathrm{D}$ & Tidak Baik \\
& $\mathrm{Sb} i$ & & \\
5. & $\mathrm{X} \leq \bar{x}-1,80 \mathrm{Sb} i$ & $\mathrm{E}$ & $\begin{array}{c}\text { Sangat Tidak } \\
\text { Baik }\end{array}$ \\
\hline
\end{tabular}

Skor aktual (x) adalah skor yang dicapai atau diperoleh. Skor tertinggi ideal didapat dari skor tertinggi tiap aspek yang dinilai (skor 4) dikalikan dengan total keselurahan aspek yang dinilai (17 aspek). Skor terendah ideal dari skor terendah tiap aspek yang dinilai (skor 1) dikalikan dengan total keseluruhan aspek yang dinilai (17 aspek). Skor rerata ideal $(\overline{\mathrm{x}})$ didapat dari hasil penjumlahan skor tertinggi ideal dengan skor terendah ideal dibagi 2 (dua). Ketiga, Besarnya simpangan baku skor ideal (SBi) didapat dari hasil pengurangan skor tertinggi ideal dengan skor terendah ideal dikalikan $1 / 6$ (satu per enam).

Tabel 2. Penilaian Skor Validasi LKPD Menjadi Skala 5

\begin{tabular}{clcc}
\hline No & Rentang Skor & Nilai & Kategori \\
\hline 1. & $57,8<\mathrm{X} \leq 68,0$ & A & Sangat Baik \\
2. & $47,6<\mathrm{X} \leq 57,8$ & B & Baik \\
3. & $37,4<\mathrm{X} \leq 47,6$ & C & Cukup \\
4. & $27,2<\mathrm{X} \leq 37,4$ & D & Tidak Baik \\
5. & $17,0 \leq \mathrm{X} \leq 27,2$ & E & Sangat Tidak \\
baik \\
\hline
\end{tabular}

Penilaian skor respon peserta terhadap LKPD yang dikembangkan disajikan pada Tabel 2. Skor aktual (x) adalah skor yang dicapai atau diperoleh. Skor tertinggi ideal didapat dari skor tertinggi tiap aspek yang dinilai (skor 5) dikalikan dengan total keseluruhan aspek yang dinilai (10 aspek). Skor terendah ideal dari skor terendah tiap aspek yang dinilai (skor 1) dikalikan dengan total keseluruhan aspek yang dinilai (10 aspek). Skor rerata ideal $(\overline{\mathrm{x}})$ didapat dari hasil penjumlahan skor tertinggi ideal dengan skor terendah ideal dibagi 2 (dua). Ketiga, Besarnya simpangan baku skor ideal (SBi) didapat dari hasil pengurangan skor tertinggi 
ideal dengan skor terendah ideal dikalikan $1 / 6$ (satu per enam).

Tabel 3. Penilaian LKPD Berdasarkan Respon Peserta Didik Menjadi Skala 5

\begin{tabular}{clcc}
\hline No & Rentang skor & Nilai & Kategori \\
\hline 1. & $42<\mathrm{X} \leq 50$ & A & Sangat Baik \\
2. & $34<\mathrm{X} \leq 42$ & B & Baik \\
3. & $26<\mathrm{X} \leq 34$ & C & Cukup \\
4. & $18<\mathrm{X} \leq 26$ & D & Tidak Baik \\
5. & $10 \leq \mathrm{X} \leq 18$ & E & Sangat Tidak baik \\
\hline
\end{tabular}

Keterlaksanaan proses pembelajaran menggunakan LKPD berbasis inkuiri terbimbing diwujudkan dalam keterlaksanaan RPP dengan skor 1 atau 0 . Total skor penilaian dianalisis untuk menentukan sebuah kategori. Pedoman konversi nilai aktual menjadi nilai kategori dapat dilihat pada Tabel 4 (Hermanto et al., 2014, pp. 369-377).

Tabel 4. Persentase dan Kategori Penilaian Keterlaksanaan RPP

\begin{tabular}{ccc}
\hline No. & Persentase (\%) & Kategori \\
\hline 1. & $80<\mathrm{x} \leq 100$ & Sangat Baik \\
2. & $60<\mathrm{x} \leq 80$ & Baik \\
3. & $40<\mathrm{x} \leq 60$ & Cukup Baik \\
4. & $20<\mathrm{x} \leq 40$ & Kurang Baik \\
5. & $0 \mathrm{x} \leq 20$ & Sangat Kurang Baik \\
\hline
\end{tabular}

Analisis data terhadap soal pretest dan posttest dengan teknik gain ternormalisasi, bertujuan untuk melihat besarnya peningkatan kemampuan keterampilan berpikir kritis dan hasil belajar kognitif yang timbul karena penggunaan LKPD tema Gunung Meletus berbasis inkuiri terbimbing dengan melihat nilai gain ternormalisasi $(<\mathrm{g}>)$ (Hake, 2007). Rumus perhitungan gain skor dan kriterianya terdapat pada Tabel 5.

Tabel 5. Perhitungan Skor Gain Ternormalisasi

\begin{tabular}{rlcc}
\hline \multicolumn{1}{c}{ Rumus } & Indeks $<\mathrm{g}>$ & Kriteria \\
\hline$<\mathrm{g}>=$ & $\frac{T 2-T 1}{I s-T 1}$ & $>0,70$ & Tinggi \\
$<\mathrm{g}>$ & $\begin{array}{l}\text { Nilai gain } \\
\text { ternormalisasi }\end{array}$ & $0,30<(<\mathrm{g}>) \leq 0,70$ & Sedang \\
$\mathrm{T} 1$ & Nilai pretest & $\leq 0,30$ & Rendah \\
$\mathrm{T} 2$ & Nilai posttest & & \\
Is & $\begin{array}{l}\text { Skor maksimal } \\
\text { ideal }\end{array}$ & & \\
& & \\
\hline
\end{tabular}

\section{HASIL DAN PENGEMBANGAN}

\section{Hasil}

Pengembangan LKPD tema Gunung Meletus berbasis inkuiri terbimbing meliputi tahap penelitian pendahuluan, perencanaan, dan pengembangan produk awal.

\section{Penelitian Pendahuluan}

Pada tahap ini penelitian pendahuluan dilakukan melalui dua cara, yaitu survei lapangan dan studi pustaka. Berdasarkan hasil wawancara yang dilakukan kepada pendidik dan hasil observasi pelaksanaan pembelajaran di kelas VII SMP Negeri 2 Cangkringan, diperoleh beberapa permasalahan dalam pembelajaran IPA, di antaranya sebagai berikut. Pertama, pelaksanaan pembelajaran IPA belum dapat dilaksanakan secara optimal. Hal ini dikarenakan pelaksanaan pembelajaran IPA masih dilaksanakan secara terpisah antara bidang kajian (Fisika, Biologi, dan Kimia), kurangnya pemahaman pendidik terhadap pembelajaran IPA secara terpadu, pendidik kesulitan dalam memadukan antar bidang kajian (Fisika, Biologi, dan Kimia) dan menentukan tema pembelajaran. Kedua, guru jarang sekali melakukan praktikum di laboratorium IPA sebagai penunjang pembelajaran IPA, hal ini terlihat dari alat-alat laboratorium yang kurang dipakai sehingga tidak terawat dan berdebu. Ketiga, LKPD yang digunakan hanya memperhatikan domain kognitif sehingga LKPD tersebut hanya digunakan sebagai tugas pekerjaan rumah, lembar kegiatan percobaan pada LKPD belum dilaksanakan, kurangnya kegiatan percobaan di laboratorium menyebabkan peserta didik kurang terampil dalam menggunakan alat laboratorium, LKPD yang digunakan pendidik juga kurang memperhatikan keterampilan berpikir kritis dan potensi dari lingkungan sekitar.

Keempat, pembelajaran IPA masih berpusat kepada pendidik dan peserta didik belum terbiasa menemukan sendiri konsep dan fakta. Hal ini menyebabkan pemahaman konsep dan keterampilan berpikir kritis peserta didik rendah, karena peserta didik sudah terbiasa diberikan langsung konsep, teori, dan fakta oleh pendidik, tanpa membiasakan proses IPA dan berpikir kritis kepada peserta didik.

Kelima, pada saat pembelajaran IPA terdapat beberapa peserta didik yang kurang bersemangat (mengantuk, bertelungkup di atas meja) ketika mengikuti pelajaran. Hal ini dikarenakan faktor kelelahan, ikut menambang pasir bersama orang tua setelah pulang dari sekolah. Adanya penambangan pasir di dekat sekolah menyebabkan beberapa peserta didik ikut mencari penghasilan untuk membantu orang tuanya. Beberapa peserta didik menyebutkan 
bahwa penghasilan dari menambang pasir digunakan untuk menambah uang jajan dan membeli beberapa perlengkapan sekolah.

Berdasarkan studi pustaka yang dilakukan, setelah mempelajari standar kompetensi (SK) dan kompetensi dasar (KD) IPA SMP kemudian dipilih SK dan KD yang akan dipadukan. Setelah pemetaan keterpaduan SK dan KD, selanjutnya memilih dan menetapkan tema pemersatu, tema materi yang akan diajarkan pada LKPD adalah Gunung Meletus (arus konveksi, penyebab erupsi, aliran lava, kekentalan magma, dan bahaya letusan serta mitigasi bencana). Hasil pemetaan tersebut dihubungkan menggunakan model webbed. Tujuan pemilihan model keterpaduan webbed atau pembelajaran tematik diharapkan membantu peserta didik untuk dapat mengkomunikasikan hasil belajar yang mereka peroleh di kelas dengan kehidupan sehari-hari, peserta didik juga diharapkan dapat menemukan sendiri berbagai konsep yang dipelajari secara menyeluruh dan bermakna. Tahap selanjutnya membuat analisis konsep, merumuskan indikator, menetapkan tujuan pembelajaran, menyusun silabus, RPP, dan LKPD.

Perencanaan

Berdasarkan dari hasil penelitian pendahuluan, spesifikasi produk awal yang dikembangkan dalam penelitian ini adalah LKPD tema Gunung Meletus berbasis inkuiri terbimbing. LKPD yang dikembangkan menggunakan langkah kegiatan proses IPA dengan berpedoman pada tahap pembelajaran inkuiri terbimbing. Karakteristik LKPD tema Gunung Meletus berbasis inkuiri terbimbing yang dikembangkan yaitu: (a) LKPD memiliki tahapan inkuiri terbimbing (membuat prediksi, melakukan penyelidikan, mengumpulkan data, menginterpretasi data, dan mengembangkan kesimpulan); (b) Tema yang diambil dekat dengan lingkungan peserta didik; (c) LKPD menyajikan serangkaian kegiatan percobaan mengenai materi gunung berapi; dan (d) Pertanyaan yang disajikan melatih keterampilan berpikir kritis.

Pengembangan Produk Awal

Tahap pengembangan produk awal ini meliputi penyusunan draft produk LKPD yang dikembangkan; validasi; serta hasil revisi draft LKPD. Pengembangan draft produk LKPD ini kemudian divalidasi oleh 2 validator ahli yang berasal dari dosen FMIPA Universitas Negeri Yogyakarta, yaitu validator ahli materi dan validator ahli media.
Data hasil penilaian LKPD oleh validator ahli (V), guru IPA (G), dan teman sejawat (TS) terdapat pada Tabel 6 . Hasil penilaian dari validator ahli, guru IPA, dan teman sejawat berupa skor yang kemudian dikonversi menjadi penilaian skala 5 (lima). Hasil pengkonversian skor menjadi skala nilai 5 (lima) disajikan pada Tabel 2 .

Penilaian terhadap LKPD tema Gunung Meletus berbasis inkuiri terbimbing yang dilakukan oleh validator ahli, guru IPA, dan teman sejawat berdasarkan Tabel 6 secara keseluruhan memiliki total rerata skor sebesar 64,3 . Total rerata skor tersebut berada dalam rentang skor $57,5<\mathrm{X} \leq 68,0$ yang termasuk kategori sangat baik dengan predikat nilai $\mathrm{A}$. Hal ini menunjukkan bahwa LKPD yang dikembangkan sudah layak untuk diujicobakan ke sekolah dengan perbaikan sesuai saran dan masukan yang diberikan.

Tabel 6. Rerata Skor Penilaian LKPD

\begin{tabular}{|c|c|c|c|c|c|}
\hline & \multirow{2}{*}{ Indikator Penilaian } & \multicolumn{3}{|c|}{ Rerata Skor } & \multirow{2}{*}{ Rerata } \\
\hline & & $V^{*}$ & $\mathrm{G}^{*}$ & TS* & \\
\hline 1. & $\begin{array}{l}\text { Kelengkapan } \\
\text { Komponen LKPD }\end{array}$ & 4,0 & 4,0 & 4,0 & 4,0 \\
\hline 2. & $\begin{array}{l}\text { Kesesuaian Isi dan } \\
\text { Materi }\end{array}$ & 16,0 & 16,0 & 16,0 & 16,0 \\
\hline 3. & $\begin{array}{l}\text { Kesesuaian Syarat } \\
\text { Inkuiri Terbimbing }\end{array}$ & 14,5 & 13,5 & 14,5 & 14,2 \\
\hline 4. & $\begin{array}{l}\text { Kesesuaian Syarat } \\
\text { Konstruksi }\end{array}$ & 15,5 & 14,5 & 14,5 & 14,8 \\
\hline 5. & $\begin{array}{l}\text { Kesesuaian Syarat } \\
\text { Teknis }\end{array}$ & 15,5 & 14,5 & 16 & 15,3 \\
\hline & Skor Total & 65,5 & 62,5 & 65,0 & 64,3 \\
\hline & Skor Tertir & 68,0 & 68,0 & 68,0 & 68,0 \\
\hline & Skor Terendah Ideal & 17,0 & 17,0 & 17,0 & 17,0 \\
\hline & Rerata Skor Ideal & 42,5 & 42,5 & 42,5 & 42,5 \\
\hline & $\begin{array}{l}\text { Simpangan Baku Skor } \\
\text { Ideal }\end{array}$ & 8,5 & 8,5 & 8,5 & 8,5 \\
\hline & Nilai & $\mathbf{A}$ & $\mathbf{A}$ & $\mathbf{A}$ & $\mathbf{A}$ \\
\hline
\end{tabular}

* validator ahli (V), guru IPA (G), dan teman sejawat (TS)

\section{Hasil Uji Coba Produk}

Uji Coba Produk Awal

Hasil respon peserta didik yang berupa skor kemudian dikonversi menjadi penilaian skala 5 (lima) seperti tersaji pada Tabel 3. Aspek respon peserta didik terhadap produk awal LKPD yang dikembangkan meliputi syarat didaktik, syarat konstruksi, dan syarat teknis. Data hasil rerata skor respon peserta didik terhadap produk awal LKPD yang dikembangkan pada uji coba terbatas disajikan pada Tabel 7. 
Tabel 7. Rerata Skor Respon Peserta Didik terhadap Produk Awal LKPD

\begin{tabular}{ccc}
\hline No. & Indikator Penilaian & Rerata Skor \\
\hline 1. & Syarat Didaktik & 12,5 \\
2. & Syarat Konstruksi & 16,0 \\
3. & Syarat Teknis & 13,1 \\
& Skor Total & $\mathbf{4 1 , 6}$ \\
& Skor Tertinggi Ideal & 50,0 \\
& Skor Terendah Ideal & 10,0 \\
& Rerata Skor Ideal & 30,0 \\
Simpangan Baku Skor Ideal & 6,7 \\
& Nilai & B \\
\hline
\end{tabular}

Berdasarkan Tabel 7 hasil respon peserta didik terhadap LKPD tema Gunung Meletus berbasis inkuiri terbimbing dilihat dari aspek syarat didaktik memiliki rerata skor sebesar 12,5; syarat konstruksi dengan rerata skor sebesar 16; dan syarat teknis dengan rerata skor sebesar 13,1. Secara keseluruhan respon peserta didik terhadap produk awal LKPD yang dikembangkan memiliki rerata skor sebesar 41,6. Skor ini berada dalam rentang skor $34<\mathrm{X} \leq 42$ yang termasuk kategori baik dengan predikat nilai $\mathrm{B}$. Hal ini menunjukkan bahwa LKPD yang dikembangkan sudah layak untuk diujicobakan di kelas eksperimen dalam uji coba produk utama.

Uji Coba Produk Utama

Proses pembelajaran di kelas eksperimen dan di kelas kontrol dilakukan oleh pendidik IPA dari sekolah tersebut. Observasi keterlaksanaan pembelajaran di kelas eksperimen yang menggunakan LKPD tema Gunung Meletus berbasis inkuiri terbimbing dilakukan oleh 2 observer, yang bertugas mengamati proses pembelajaran sesuai dengan aspek yang ada dalam lembar observasi yang telah disediakan.

Keterlaksanaan proses pembelajaran menggunakan LKPD berbasis inkuiri terbimbing diwujudkan dalam keterlaksanaan RPP dengan memberi tanda di kolum "Ya" atau "Tidak" dalam setiap aspek yang dinilai. Persentase keterlaksanaan pembelajaran menggunakan LKPD tema Gunung Meletus berbasis inkuiri terbimbing pada kelas eksperimen disajikan pada Tabel 8.

Pembelajaran IPA di kelas eksperimen dengan menggunakan LKPD tema Gunung Meletus berbasis inkuiri terbimbing secara umum proses pelaksanaannya berjalan dengan sangat baik. Rerata persentase keterlaksanaan pembelajaran di kelas tersebut mencapai angka 94,76\%. Persentase keterlaksanaan pembelajaran menggunakan LKPD berbasis inkuiri terbimbing yang tertinggi berada di pertemuan kedua dengan menggunakan LKPD 02, dengan angka persentase mencapai 97,62\%.

Tabel 8. Persentase Keterlaksanaan Pembelajaran Kelas Eksperimen

\begin{tabular}{cccccc}
\hline \multirow{2}{*}{ No. } & \multirow{2}{*}{ Pertemuan } & \multicolumn{3}{c}{ Frekuensi } & \multicolumn{2}{c}{ Persentase (\%) } \\
\cline { 3 - 6 } & & Ya & Tidak & Ya & Tidak \\
\hline 1. & LKPD 01 & 40 & 2 & 95,24 & 4,76 \\
2. & LKPD 02 & 41 & 1 & 97,62 & 2,38 \\
3. & LKPD 03 & 39 & 3 & 92,86 & 7,14 \\
4. & LKPD 04 & 40 & 2 & 95,24 & 4,76 \\
5. & LKPD 05 & 39 & 3 & 92,86 & 7,14 \\
& Rerata & 39,8 & 2,2 & $\mathbf{9 4 , 7 6}$ & 5,24 \\
Kriteria Penilaian & \multicolumn{4}{c}{ Sangat Baik } \\
\hline
\end{tabular}

Skor pretest dan posttest keterampilan berpikir kritis peserta didik yang diperoleh dikonversi ke dalam skor nilai 100 . Hasil perhitungan skor pretest dan posttest keterampilan berpikir kritis peserta didik menggunakan gain score tersaji pada Tabel 9.

Tabel 9. Gain Score Keterampilan Berpikir Kritis Kelas Eksperimen

\begin{tabular}{ccccc}
\hline No. & Nilai & $\mathbf{P}_{\mathbf{1}}{ }^{*}$ & $\mathbf{P}_{\mathbf{2}}{ }^{*}$ & $\mathbf{G S}^{*}$ \\
\hline 1. & Tertinggi & 66,67 & 87,50 & 0,67 \\
2. & Terendah & 33,33 & 58,33 & 0,25 \\
3. & Rerata & 53,13 & 72,66 & $\mathbf{0 , 4 3}$ \\
4. & Std. Deviasi & 7,99 & 8,19 & 0,11 \\
& Kriteria GS & \multicolumn{3}{c}{ Sedang } \\
\hline
\end{tabular}

*pretest $\left(\mathrm{P}_{1}\right)$, posttest $\left(\mathrm{P}_{2}\right)$, dan gain score $(\mathrm{GS})$

Berdasarkan Tabel 9 tersebut diketahui bahwa rerata gain score keterampilan berpikir kritis peserta didik di kelas eksperimen mencapai angka 0,43 dengan standar deviasi 0,11. Hasil dari rerata gain score tersebut berada dalam kategori sedang (kriteria indeks gain score tersaji pada Tabel 5). Sedangkan di kelas kontrol disajikan pada Tabel 10, rerata gain score keterampilan berpikir kritis peserta didik sebesar 0,33 dengan standar deviasi sebesar 0,12 yang berada dalam interval kategori dengan kriteria sedang.

Tabel 10. Gain Score Keterampilan Berpikir Kritis Kelas Kontrol

\begin{tabular}{clccc}
\hline No. & \multicolumn{1}{c}{ Nilai } & $\mathbf{P}_{\mathbf{1}}{ }^{*}$ & $\mathbf{P}_{2}{ }^{*}$ & $\mathbf{G S}^{*}$ \\
\hline 1. & Tertinggi & 62,50 & 83,33 & 0,64 \\
2. & Terendah & 37,50 & 58,33 & 0,09 \\
3. & Rerata & 50,52 & 67,19 & $\mathbf{0 , 3 3}$ \\
4. & Std. Deviasi & 6,50 & 6,24 & 0,12 \\
& Kriteria GS & \multicolumn{3}{c}{ Sedang } \\
\hline
\end{tabular}

*pretest $\left(\mathrm{P}_{1}\right)$, posttest $\left(\mathrm{P}_{2}\right)$, dan gain score $(\mathrm{GS})$

Walaupun kedua gain score tersebut berada dalam interval kategori yang sama, yaitu kriteria sedang, gain score di kelas eksperimen 
lebih tinggi apabila dibandingkan dengan gain score di kelas kontrol. Hal ini menunjukkan bahwa pembelajaran menggunakan LKPD tema Gunung Meletus berbasis inkuiri terbimbing mampu meningkatkan keterampilan berpikir kritis peserta didik.

Pengambilan data hasil belajar peserta didik juga menggunakan pretest dan posttest pada saat sebelum dan sesudah proses pembelajaran dilaksanakan yang dilakukan di kelas eksperimen dan kontrol. Hasil perhitungan skor pretest dan posttest hasil belajar peserta didik kelas kontrol menggunakan gain score tersaji pada Tabel 11.

Tabel 11. Gain Score Hasil Belajar Kelas Eksperimen

\begin{tabular}{ccccc}
\hline No. & Nilai & $\mathbf{P}_{\mathbf{1}}$ * & $\mathbf{P}_{\mathbf{2}}$ * & $\mathbf{G S}^{*}$ \\
\hline 1. & Tertinggi & 87,50 & 93,75 & 0,75 \\
2. & Terendah & 43,75 & 68,75 & 0,00 \\
3. & Rerata & 70,70 & 80,66 & $\mathbf{0 , 3 5}$ \\
4. & Std. Deviasi & 9,97 & 7,84 & 0,16 \\
& Kriteria GS & \multicolumn{3}{c}{ Sedang } \\
\hline
\end{tabular}

*pretest $\left(\mathrm{P}_{1}\right)$, posttest $\left(\mathrm{P}_{2}\right)$, dan gain score $(\mathrm{GS})$

Rerata gain score hasil belajar peserta didik di kelas eksperimen berdasarkan Tabel 11 mencapai angka 0,34 dengan nilai standar deviasi sebesar 0,16. Hasil dari rerata gain score tersebut berada dalam kategori sedang. Sedangkan di kelas kontrol, rerata gain score hasil belajar peserta didik seperti yang disajikan pada Tabel 12 adalah sebesar 0,15 dengan nilai standar deviasi 0,14 yang berada pada interval indeks gain score kurang dari 0,3 dengan kriteria rendah. Kriteria indeks gain score disajikan pada Tabel 5. Hasil tersebut menunjukkan gain score di kelas eksperimen lebih tinggi dibandingkan dengan gain score di kelas kontrol. Berdasarkan hasil tersebut dapat dikatakan bahwa pembelajaran menggunakan LKPD tema Gunung Meletus berbasis inkuiri terbimbing mampu meningkatkan hasil belajar peserta didik.

Tabel 12. Gain Score Hasil Belajar Kelas Kontrol

\begin{tabular}{clccc}
\hline No. & \multicolumn{1}{c}{ Nilai } & $\mathbf{P}_{\mathbf{1}}{ }^{*}$ & $\mathbf{P}_{2}{ }^{*}$ & $\mathbf{G S}^{*}$ \\
\hline 1. & Tertinggi & 81,25 & 87,50 & 0,40 \\
2. & Terendah & 56.25 & 62,50 & $-0,33$ \\
3. & Rerata & 67,38 & 72,85 & $\mathbf{0 , 1 5}$ \\
4. & Std. Deviasi & 8,66 & 6,47 & 0,14 \\
& Kriteria GS & \multicolumn{3}{c}{ Rendah } \\
\hline
\end{tabular}

*pretest $\left(\mathrm{P}_{1}\right)$, posttest $\left(\mathrm{P}_{2}\right)$, dan gain score $(\mathrm{GS})$

Setelah dilaksanakan uji prasyarat berupa uji normalitas dan homogenitas yang menunjukkan bahwa data peningkatan keterampilan berpikir kritis dan hasil belajar peserta didik semua data berdistribusi normal dan berasal dari populasi yang homogen, maka dilanjutkan dengan uji multivariate analysis of variance (manova).

Hasil uji manova digunakan untuk mengukur pengaruh atau perbedaan antara kelas eksperimen dengan kelas kontrol terhadap keterampilan berpikir kritis dan hasil belajar peserta didik. Uji statistik yang digunakan adalah Hotelling's Trace, karena terdapat 2 variabel dependen dalam penelitian ini, yaitu keterampilan berpikir kritis dan hasil belajar peserta didik. Sedangkan variabel independennya adalah kelas, dengan kategori kelas eksperimen (menggunakan LKPD yang dikembangkan) dan kelas kontrol (menggunakan LKPD pendidik). Hasil analisis multivariat perbedaan peningkatan gain score keterampilan berpikir kritis dan hasil belajar antara kelas eksperimen dengan kelas kontrol seperti yang tersaji pada Tabel 13.

Box's test covarian matrices digunakan untuk menguji hipotesis apakah matriks kovarian dari variabel dependen yang sama untuk kedua kelas (eksperimen dan kontrol), dengan asumsi jika nilai $p$-value (sig.) $\geq 0,05$. Berdasarkan hasil uji Box's covarian matrices pada Tabel 13, kedua kelas memiliki nilai sig. sebesar 0,731. Hal ini menunjukkan bahwa kedua kelas tersebut memiliki matrik kovarian dari variabel dependen yang sama, karena nilai sig. $0,731 \geq 0,05$.

Tabel 13. Hasil Uji Multivariat

\begin{tabular}{clcl}
\hline No. & \multicolumn{1}{c}{ Uji } & Statistik & \multicolumn{1}{c}{ Keterangan } \\
\hline 1. & Uji Homogenitas & $0,731>$ & Kedua kelas \\
& Kovarian (Box's & 0,05 & memiliki \\
& Test) & & matriks kovarian \\
& & & yang sama \\
2. & Hotelling's Trace & $0,000<$ & Ada pengaruh \\
& & 0,05 & \\
\hline
\end{tabular}

Berdasarkan data uji Hotelling's Trace pada Tabel 13, variabel independen (kelas) memiliki nilai Sig. 0,000 kurang dari nilai $\alpha$ $(0,05)$. Hal ini mengindikasikan bahwa variabel independen atau kelas (eksperimen dan kontrol) berpengaruh terhadap peningkatan keterampilan berpikir kritis dan hasil belajar peserta didik. Perbedaan pengaruh perlakuan pada masingmasing kelas menyebabkan perbedaan peningkatan skor keterampilan berpikir kritis dan hasil belajar peserta didik. Di mana kelas eksperimen diberikan perlakuan menggunakan LKPD tema 
Gunung Meletus berbasis inkuiri terbimbing, sedangkan kelas kontrol diberikan perlakuan menggunakan LKPD dari pendidik di sekolah tersebut.

Pengaruh faktor atau between-subject effect variabel independen (kelas) terhadap variabel dependen (gain score keterampilan berpikir kritis dan hasil belajar) disajikan pada Tabel 14.

\section{Tabel 14. Uji Between-Subject Effects}

\begin{tabular}{|c|c|c|c|}
\hline $\begin{array}{c}\text { Variabel } \\
\text { Dependen }\end{array}$ & $\begin{array}{c}\text { Variabel } \\
\text { Independen }\end{array}$ & Mean Sig. & Keterangan \\
\hline$G S \mathrm{KBK}^{*}$ & $\begin{array}{l}\text { Eksperimen } \\
\text { Kontrol }\end{array}$ & $\begin{array}{l}0,427 \\
0,332\end{array} \quad 0,002$ & $\begin{array}{c}\text { Ada } \\
\text { Perbedaan }\end{array}$ \\
\hline$G S \mathrm{HB}^{* *}$ & $\begin{array}{l}\text { Eksperimen } \\
\text { Kontrol }\end{array}$ & $\begin{array}{l}0,345 \\
0,151\end{array} 0,000$ & $\begin{array}{c}\text { Ada } \\
\text { Perbedaan }\end{array}$ \\
\hline
\end{tabular}

* GS KBK (gain score Keterampilan Berpikir Kritis)

** GS HB (gain score Hasil Belajar)

Pada Tabel 14 dapat dilihat pengaruh kelas terhadap variabel dependen. Pada kolum Sig. ternyata gain score keterampilan berpikir kritis mempunyai nilai Sig. sebesar 0,002 dan gain score hasil belajar mempunyai nilai Sig. 0,000 . Kedua variabel dependen tersebut mempunyai nilai $\mathrm{Sig} \leq \alpha(0,05)$, maka $\mathrm{H}_{0}$ ditolak. Berdasarkan hasil tersebut menunjukkan bahwa ada pengaruh faktor variabel independen (kelas) pada variabel dependen (gain score keterampilan berpikir kritis dan hasil belajar). Dengan kata lain terdapat perbedaan yang signifikan mengenai peningkatan keterampilan berpikir kritis dan hasil belajar peserta didik antara kelas eksperimen dengan kelas kontrol.

Perbedaan yang signifikan mengenai keterampilan berpikir kritis dan hasil belajar peserta didik antara kelas eksperimen dengan kelas kontrol juga dapat dilihat dari membandingkan hasil rerata gain score variabel dependen pada kelas eksperimen dengan kelas kontrol. Rerata gain score keterampilan berpikir kritis $(0,427)$ dan gain score hasil belajar $(0,345)$ peserta didik di kelas eksperimen lebih tinggi apabila dibandingkan dengan gain score keterampilan berpikir kritis $(0,332)$ dan hasil belajar $(0,151)$ peserta didik di kelas kontrol.

\section{Revisi Produk}

LKPD tema Gunung Meletus berbasis inkuiri terbimbing yang dikembangkan dalam penelitian ini melewati tiga tahap revisi produk. Tahap pertama adalah revisi draf produk awal setelah dilakukan penilaian oleh validator ahli (materi dan media), guru IPA, dan teman sejawat. Tahap kedua, revisi produk awal setelah dilakukan uji coba terbatas. Terakhir, tahap revisi produk akhir setelah dilakukan uji coba utama.

Pada tahap ini draf produk awal direvisi berdasarkan hasil penilaian, saran, dan masukan dari validator ahli (materi dan media), guru IPA, dan teman sejawat, serta masukan dari dosen pembimbing. Perbaikan terhadap draf produk awal tersebut antara lain: (1) perbaikan kalimat yang lebih sederhana pada tujuan pembelajaran di LKPD, agar peserta didik memahami maksud dari tujuan yang akan dicapai; (2) tujuan penyelidikan pada LKPD 01 sampai LKPD 05 jangan berupa kalimat tanya; (3) pada bagian membuat prediksi, diberi contoh kalimat prediksi. Sehingga peserta didik lebih mudah memahami, karena sebagian besar peserta didik SMP, apalagi kelas VII itu belum mengetahui bagaimana cara membuat kalimat prediksi yang baik; (4) prosedur kegiatan menggunakan kata awalan berupa kata instruksi (kalimat perintah) jangan menggunakan kata awalan berupa kata kerja; (5) tabel pengamatan disesuaikan dengan apa yang mau diamati, (6) beberapa pertanyaan di perbaiki susunan kalimatnya agar peserta didik memahami maksud dari pertanyaan tersebut; dan (7) buat skema keterhubungan konsep per LKPD, agar peserta didik lebih memahami maksud dari tujuan penyelidikan yang akan dilakukan.

Revisi produk awal dilakukan setelah uji coba terbatas. Hasil respon peserta didik terhadap LKPD yang dikembangkan kemudian dianalisis semua data dan informasi untuk dilakukan revisi sehingga nantinya produk siap diujicobakan. Beberapa masukan peserta didik di antaranya pada beberapa kalimat pertanyaan, mereka merasa kesulitan menangkap maksud dari pertanyaan. Pertanyaan tersebut kemudian direvisi agar lebih mudah dipahami peserta didik.

Tahap revisi produk akhir dilakukan setelah uji coba utama. Beberapa revisi pada produk utama LKPD tema Gunung Meletus berbasis inkuiri terbimbing yang dikembangkan antara lain: (1) Pergantian dan pengurangan alat dan bahan pada LKPD 02, alat berupa kertas tisu dihilangkan karena kertas tisu yang digunakan dalam penyelidikan tidak mudah terurai saat dimasukkan ke dalam larutan, pergantian bahan yang pada mulanya menggunakan air jeruk diganti menggunakan deterjen, Penggunaan deterjen dimaksudkan untuk menambah efek letusan yang dikeluarkan; (2) pergantian dan pengurangan alat pada LKPD 03, alat penetes 
mata diganti dengan pipet tetes, batu atau balok kayu sebagai penyangga tempat aliran diganti dengan kaki tiga, lidi yang digunakan untuk membuat sekat atau grid dihilangkan, pembuatan grid jarak digunakan menggunakan garis saja; dan (3) Pergantian dan modifikasi prosedur kegiatan pada LKPD 02, pengurangan alat kertas tisu dan bahan dari air jeruk ke deterjen menyebabkan susunan prosedur kegiatan dalam LKPD 02 tersebut di perbaiki.

\section{Kajian Produk Akhir}

Penelitian pengembangan ini menghasilkan produk akhir berupa LKPD tema Gunung Meletus berbasis inkuiri terbimbing yang dapat meningkatkan keterampilan berpikir kritis dan hasil belajar peserta didik. Produk LKPD tema Gunung Meletus ini memiliki karakteristik, di antaranya yaitu: (1) memiliki tahapan inkuiri terbimbing (membuat prediksi, melakukan penyelidikan, mengumpulkan data, menginterpretasi data, dan mengembangkan kesimpulan); mengambil tema yang dekat dengan lingkungan peserta didik; menyajikan kegiatan penyelidikan yang dirancang untuk melatih keterampilan berpikir kritis, pertanyaan yang disajikan dalam LKPD diharapkan dapat meningkatkan kemampuan keterampilan berpikir kritis dan hasil belajar peserta didik.

Pada saat uji coba utama penggunaan LKPD tema Gunung Meletus berbasis inkuiri terbimbing, ada beberapa hal yang ditemukan saat proses pembelajaran berlangsung, di antaranya sebagai berikut (1) peserta didik aktif dan sangat antusias melakukan penyelidikan sesuai dengan prosedur kerja yang tercantum dalam LKPD sehingga pembelajaran yang menyenangkan dan bermakna tercapai; (2) kegiatan yang ada di LKPD dilakukan secara berkelompok sehingga sikap kerjasama antar anggota kelompok terjalin dengan baik (3) munculnya sikap kritis peserta didik saat kegiatan di pertemuan kedua, beberapa kelompok yang lebih cepat melakukan penyelidikan LKPD 02 mengenai erupsi gunung berapi menemui kendala, di mana penyelidikan kelompok mereka tidak berhasil, gunung berapi yang mereka rancang tidak berhasil meletus; (4) pendidik yang berperan sebagai fasilitator dalam kegiatan penyelidikan LKPD 02 mengenai erupsi gunung berapi, mempertanyakan kesesuaian prosedur yang dipakai, ternyata hal itu dikarenakan kertas tisu yang digunakan dalam penyelidikan tersebut tidak cepat terurai, sehingga proses erupsi tidak berjalan; (5) munculnya masukan dari peserta didik sebagai salah satu hasil dari kemampuan berpikir kritis. Peserta didik memberikan saran kepada pendidik untuk menghilangkan kertas tisu dan memodifikasi prosedur kerja disertai dengan alasan yang cukup kuat, berdasarkan hal tersebut pendidik dan peneliti menyetujuinya; dan (6) terjadinya modifikasi prosedur kerja pada kegiatan LKPD 02 mengenai erupsi gunung berapi saat proses pembelajaran berlangsung, perubahan prosedur kerja tersebut sebagai masukan pada revisi produk akhir.

Produk LKPD tema Gunung Meletus berbasis inkuiri terbimbing yang dikembangkan ini meskipun dalam penilaiannya secara umum berkualitas sangat baik dan dapat meningkatkan keterampilan berpikir kritis dan hasil belajar peserta didik, namun dalam pengembangannya masih memiliki beberapa kelemahan. Kelemahan itu terdapat pada skala uji coba produk, hanya dilakukan dalam skala kecil yang melibatkan 1 (satu) sekolah. Uji coba produk ini juga hanya dilakukan pada kelas VIIA saja dengan jumlah 32 peserta didik yang mewakili tingkat kemampuan atas, sedang, dan bawah.

\section{SIMPULAN}

Berdasarkan hasil penelitian dan pengembangan, dapat disimpulkan bahwa: (1) produk yang dihasilkan berupa LKPD tema Gunung Meletus berbasis inkuiri terbimbing, dengan karakteristik meliputi tahapan membuat prediksi, melakukan penyelidikan, mengumpulkan data, menginterpretasi data, dan mengembangkan kesimpulan; (2) hasil penilaian oleh validator ahli, guru IPA, dan teman sejawat menunjukkan bahwa rerata penilaian masuk kategori sangat baik, sehingga LKPD tema Gunung Meletus berbasis inkuiri terbimbing layak digunakan dalam pembelajaran IPA; (3) LKPD tema Gunung Meletus berbasis inkuiri terbimbing mampu meningkatkan keterampilan berpikir kritis peserta didik sebesar 0,43 termasuk kategori sedang; dan (4) LKPD tema Gunung Meletus berbasis inkuiri terbimbing mampu meningkatkan hasil belajar peserta didik sebesar 0,34 termasuk kategori sedang.

Berdasarkan simpulan di atas, saran yang dapat direkomendasikan yaitu (1) LKPD tema Gunung Meletus berbasis inkuiri terbimbing hendaknya digunakan dalam pembelajaran IPA, karena LKPD ini menuntut peserta didik lebih aktif dalam proses pembelajaran dan pembelajaran yang menyenangkan serta bermakna dapat tercapai; dan (2) LKPD tema Gunung Meletus berbasis inkuiri terbimbing diharapkan 
dapat digunakan dalam kurikulum muatan lokal bagi sekolah yang lokasinya berdekatan dengan kawasan gunung berapi. Hal ini karena keterbatasan alokasi jam pelajaran IPA di kurikulum nasional yang hanya menyediakan 2 sampai 4 jam pelajaran mengenai gunung berapi.

\section{DAFTAR PUSTAKA}

Anderson, L. W., \& Krathwohl, D. R. (2010). Kerangka landasan untuk pembelajaran, pengajaran dan asesmen: Revisi taksonomi pendidikan Bloom (A. Prihant). Yogyakarta: Pustaka Pelajar. https://doi.org/2010

Blanchard, M. R., Southerland, S. A., Osborne, J. W., Sampson, V. D., Annetta, L. A., \& Granger, E. M. (2010). Is inquiry possible in light of accountability?: A quantitative comparison of the relative effectiveness of guided inquiry and verification laboratory instruction. Science Education, 94(4), 577-616. https://doi.org/10.1002/sce.20390

Borg, W. R., \& Gall, M. D. (1983). Educational research: An introduction. New York: Longman.

Buxton, C. A., \& Provenzo, E. F. (2011). Teaching science in elementary \&amp; middle school: a cognitive and cultural approach. SAGE Publications.

Chase, A., Pakhira, D., \& Stains, M. (2013). Implementing process-oriented, guidedinquiry learning for the first time: Adaptations and short-term impacts on students' attitude and performance. Journal of Chemical Education, 90(4), 409-416.

https://doi.org/10.1021/ed300181t

Chiappetta, E. L., \& Koballa, T. R. (2010). Science instruction in the middle and secondary schools: Developing fundamental knowledge and skills. New York: Allyn \& Bacon.

Departemen Pendidikan Nasional. (2011). Panduan pengembangan pembelajaran IPA secara terpadu. Jakarta: Pusat Kurikulum, Balitbang Depdiknas.

Erminingsih, E., Sudarisman, S., \& Suparmi, S. (2012). Pembelajaran biologi model PBM menggunakan LK terbimbing dan LK bebas termodifikasi ditinjau dari KPS dan kemampuan berpikir analitis. In Prosiding Seminar Biologi (Vol. 9, pp. 203-210).
Surakarta: Universitas Sebelas Maret. Retrieved from http://jurnal.fkip.uns.ac.id/index.php/pros bio/article/view/1080

Facione, P. A. (2013). Critical thinking: What it is and why it counts. Insight Assesment. Millbrae, CA: Measured Reasons and The California Academic Press. Retrieved from https://www.nyack.edu/files/CT_What_W hy_2013.pdf

Fogarty, R. (2009). How to integrate the curricula. Thousand Oaks: Corwin.

Foley, B. J., Mcphee, C., \& Consulting, M. (2008). Students' attitudes towards science in classes using hands-on or textbook based curriculum. American Educational Research Association. Retrieved from http://www.csun.edu/ bfoley/Foley\&McP hee AERA08.pdf

Goldston, M. J., \& Downey, L. (2013). Your science classroom: Becoming an elementary/middle school science teacher. SAGE Publications.

Hake, R. (2007). Cognitive science and physics education research: What we've got here is failure to communicate. Journal of Learning Sciences , 1-12. Retrieved from http://www.physics.indiana.edu/ hake/CS \&PER-JLS7.pdf

Hermanto, F., Prastiwi, M. S., \& Rosdiana, L. (2014). Pengembangan LKS IPA discovery berdasarkan Kurikulum 2013 materi mitigasi bencana untuk siswa kelas VIII SMP. Pendidikan Sains, 2(2), 369$377 . \quad$ Retrieved from http://jurnalmahasiswa.unesa.ac.id/index. $\mathrm{php} /$ pensa/article/view/8053

Kementerian Pendidikan dan Kebudayaan. (2014). Buku guru: Ilmu pengetahuan alam. Jakarta: Kementerian Pendidikan dan Kebudayaan.

Kuhlthau, C. C., Maniotes, L. K., \& Caspari, A. K. (2007). Guided inquiry: Learning in the 21st century. Libraries Unlimited.

Ministry of Education Malaysia. (2002). Integrated curriculum for secondary schools. Kuala Lumpur: Curriculum Development Centre Ministry of Education Malaysia. Retrieved from http://smjk.edu.my/attach//resource/9380c 5f9992a4f5ec34261b1ad611409- 
Muhammad Firdaus, Insih Wilujeng

hsp_maths_f2.pdf

Pellegrino, J. W., Wilson, M. R., Koenig, J. A., \& Beatty, A. S. (2014). Developing assessments for the next generation science standards. Washington, D.C.: The National Academies Press. Retrieved from

http://www.nap.edu/catalog.php?record_i $\mathrm{d}=18409$

Peraturan Menteri Pendidikan dan Kebudayaan Republik Indonesia. Peraturan Menteri Pendidikan dan Kebudayaan RI nomor 61, tahun 2014, tentang kurikulum tingkat satuan pendidikan pada pendidikan dasar dan pendidikan menengah, Pub. L. No. 61, Peraturan Menteri (2014).

Poon, C.-L., Lee, Y.-J., Tan, A.-L., \& Lim, S. S. L. (2012). Knowing inquiry as practice and theory: Developing a pedagogical framework with elementary school teachers. Research in Science Education, 42(2), 303-327. https://doi.org/10.1007/s11165-010-91999

Prasetyo, Z. K. (2013). Pembelajaran sains berbasis kearifan lokal. In Seminar Nasional Fisika dan Pendidikan Fisika $\mathrm{Ke}-3$. Surakarta: Universitas Sebelas Maret.

Sanni, M., \& Lestari, H. P. (2011). Developing student worksheet in English based on constructivism using problem solving approach for mathematics learning on the topic of social arithmetics. In PROCEEDINGS International Seminar and the Fourth National Conference on Mathematics Education. Yogyakarta: Universitas Negeri Yogyakarta. Retrieved from http://eprints.uny.ac.id/2135/
Stoffels, N. T. (2005). "There is a worksheet to be followed": A case study of a science teacher's use of learning support texts for practical work. African Journal of Research in Mathematics, Science and Technology Education, 9(2), 147-157. https://doi.org/10.1080/10288457.2005.10 740585

Sukardjo, S. (2013). Evaluasi pembelajaran IPA untuk mahasiswa S2 Program Studi Pendidikan Sains. Yogyakarta: Program Pascasarjana Universitas Negeri Yogyakarta.

Trianto, T. (2010a). Mendesain model pembelajaran inovatif-progresif: konsep, landasan, dan imlementasinya pada kurikulum tingkat satuan pendidikan (KTSP). Jakarta: Kencana.

Trianto, T. (2010b). Model pembelajaran terpadu: Konsep, strategi, dan implementasinya dalam Kurikulum Tingkat Satuan Pendidikan (KTSP). Jakarta: Bumi Aksara. https://doi.org/2010

Yuniasih, F. (2011). Pengembangan LKPD "be a scientist" dalam pemelajaran IPA SMP untuk meningkatkan keterampilan proses peserta didik SMP kelas VII. Universitas Negeri Yogyakarta.

Zulaiha, F., Liliawati, W., \& Ramalis, T. R. (2014). Pembelajaran terpadu tema gunung meletus berorientasi peningkatan hasil belajar menurut a new taxonomy for science education. Jurnal Inovasi Dan Pembelajaran Fisika, 1(1), 22-27. Retrieved from https://ejournal.unsri.ac.id/index.php/jipf/ article/view/1060 